\section{Solid, men ikke virkelig inspirerende om ledelse}

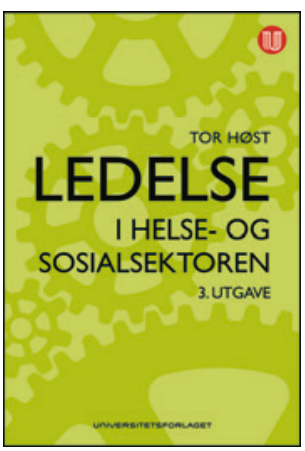

\author{
Tor Høst \\ Ledelse i helse- og sosialsektoren \\ 3. utg. 313 s, ill. Oslo: Universitetsforlaget, \\ 2014. Pris NOK 389 \\ ISBN 978-82-15-02150-8
}

Nye elementer i denne tredje utgaven er omtale av to nye ledelsesmodeller, Lean-produksjon, innflytelsesstrategier og nye forskningsresultater om New Public Management.

Målgruppen er ledere og studenter i ledelse. Formålet er å gi oversikt over hele kompleksiteten i ledelsessituasjonen i helse- og sosialsektoren og hjelp til økt trygghet i lederrollen. Tryggheten skal oppnås gjennom korrekt analyse av ledelsesutfordringene og integrering av ledelsesteorier som har vist seg å være effektfulle. Forfatteren mener at sektoren preges av at det ofte er uklare eller komplekse mål og uklare beslutningsstrukturer, og at dette legger føringer for ledelsesoppgaven. Han mener like fullt at det finnes et handlingsrom for ledere til å påvirke situasjonen, og ønsker å presentere forskjellige virkemidler for hvordan dette kan gjøres.

De fem hoveddelene omhandler helse- og sosialsektoren, hva ledelse er, ledelsestrender, konflikthåndtering og en oppsummering som inkluderer en modell som skal gi et helhetlig perspektiv på ledelse. Forfatteren konkluderer også med at kompleksiteten i helsesektoren innebærer at ledelsen blir effektfull dersom lederne klarer å finne den riktige balansen mellom tre forskjellige lederroller: den administrative, den kunstneriske og den politiske. Han forklarer hvorfor alle disse tre elementene har betydning.

Både beskrivelsen av sektoren og ledelseshistorikken, med særlig vekt på New Public Management, făr relativt god plass, og det er nyttig siden det danner bakgrunnen for mange av hoveddiskusjonene om hva som fungerer godt og dårlig i ledelse, og styring av norsk helsetjeneste.

Forskningsmiljøene i ledelse er i det store og hele enige om at det er vanskelig å enes om én særskilt ledelsesteori som gir alle de rette svarene. Derfor er det mange forskjellige teorier, noe som kan være frustrerende fordi en som gammel eller ny leder ofte er ute etter praktiske, effektfulle tips og metoder. Likevel er det bra med gjennomgangen av forskjellige teorier som preger helsetjenesten.

Kapitlet om konflikthåndtering er viktig fordi dette er noe de fleste ledere synes er aller vanskeligst, samtidig som riktig håndtering av konflikter er avgjørende på de fleste arbeidsplasser.

Boken er presis i språk og behandling av tematikk, noe som gjør at den også kan virke for kortfattet og med tendens til oppramsing. Det gjør at det kan være mer forvirrende enn opplysende å lese den $i$ ett strekk, mens den kan fungere godt som arbeidsbok og oppslagsbok underveis. Mens særlig kapitlene som beskriver sektor og ledelsestrender kan være interessante for alle som er interessert i ledelse, tror jeg andre deler vil være mest nyttig for de som allerede er ledere. Boken er solid og opplysende, men praktiske råd kunne vært tydeliggjort, og formen gjør at den ikke er blant de mest inspirerende og motiverende bøkene jeg har lest om ledelse.

\section{Lege på heltid - distriktsmedisin i gamle dager}

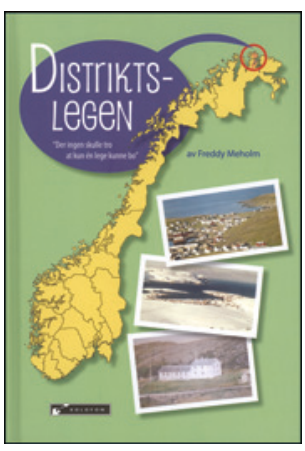

\author{
Freddy Meholm \\ Distriktslegen \\ «Der ingen skulle tro at kun én lege kunne \\ bo». 214 s, ill. Oslo: Kolofon forlag, 2014. \\ Pris NOK 278 \\ ISBN 978-82-300-1164-5
}

Freddy Meholm, født 1938, kom som nyutdannet lege til Finnmark i 1965. Han jobbet som distriktslege i Gamvik kommune i fire år. I perioder fungerte han som eneste lege for tre kommuner: Berlevåg, Gamvik og Lebesby, et areal på 6000 km². Sykebesøk og utekontordager var strevsomme og ble foretatt enten med legeskyssbåt eller legens egen 21 fot store fritidsbåt. Dessuten kunne disse også foregå med ski eller egen snøscooter.

I 28 kapitler forteller Meholm om sitt virke som lege, møtet med folket og Finnmarks storslåtte natur. Hans forkjærlighet for landskapet og store sympati for innbyggerne går tydelig frem av teksten. Forfatteren og hans unge familie syns å ha blitt tatt godt imot av finnmarkingene. Det hendte at hans egne barn ble tatt med på sykebesøk, ofte en tur på mange timer med scooter eller liten båt i Nordishavet.

Boken er lettlest, dels spennende og for det meste underholdende. Den gir et godt historisk innblikk i forholdene etter den annen verdenskrig. Jeg lot meg imponere av engasjementet Meholm viser $i$ forhold til å betjene en så utsatt stilling, $i$ tillegg til vågemotet når det gjelder å ferdes i en liten båt i Norges nordligste og mest utsatte kyststrøk.

For den yngre generasjonen gir boken et viktig innblikk i ansvaret og oppgavene som var tillagt en stilling som distriktslege i et grisgrendt strøk. Døgnkontinuerlige vakter, svært lang avstand til sykehus, få hjelpemidler, strevsomme og langvarige sykebesøk og til dels svært lite søvn er noen av stikkordene. Han beskriver på en fin måte viktigheten av grundig planlegging i forhold til naturkreftene og den ubetingede hjelpsomheten og gjestfriheten befolkningen i Distrikts-Norge er kjent for. Allerede i 1960-årene tenkte han på kunnskapsoverføring til andre yrkesgrupper som sykepleiere, jordmødre eller frivillige $\mathrm{i}$ hjelpekorpset. Historiene handler ofte om hjemmebesøkene på de mest avsidesliggende plassene. Mye dreier seg om turene til og fra sykebesøkene som kunne være vel spennende.

Det overrasker meg at forfatteren bruker full identitet på pasienter han forteller om. Om personene er fiktive, eller om forfatteren har innhentet tillatelse fra disse, blir ikke nevnt. Om så ikke er tilfelle, er det etter mitt syn et brudd på taushetsplikten og burde vært rettet opp snarest.

Personlig synes jeg at noen kapitler om lokale hverdagshendelser, 17. mai, idrettsarrangementer o.l., er noe kjedsommelig lesing for en som ikke har lokal tilhørighet. Dette ville passet bedre inn i en årbok for Gamvik kommune. Totalt sett likte jeg boken godt og kan anbefale den videre.

Frank Hilpüsch

Kommunelege, Bjarkøy 